\title{
Floristic Research of the Biological Reserve "Bragunsky"
}

\section{A Taisumov¹, M U Umarov¹, M A-M Astamirova ${ }^{2}$, A A Abumuslimov², E R Baibatyrova ${ }^{2}$, A S Abdurzakova ${ }^{3}$, R S Magomadova ${ }^{3}$, and S A Israilova ${ }^{3}$}

${ }^{1}$ Academy of Sciences of the Chechen Republic, Kh. Ibragimov Complex Institute of the Russian Academy of Sciences, Department of Biological and Medical research, Grozny, Russia

${ }^{2}$ Academy of Sciences of the Chechen Republic Department of Biological and Medical Research, Grozny, Russia

${ }^{3}$ Faculty of Natural Sciences, Chechen State Pedagogical University, Grozny, Russia

Corresponding Author:

M A Taisumov

musa_taisumov@mail.ru

Received: 25 October 2019

Accepted: 15 November 2019

Published: 25 November 2019

Publishing services provided by Knowledge E

(c) M A Taisumov et al. This article is distributed under the terms of the Creative Commons

Attribution License, which

permits unrestricted use and

redistribution provided that the

original author and source are

credited.

Selection and Peer-review under the responsibility of the AgroSMART 2019 Conference Committee.

\section{Abstract}

Flora of the biological reserve "Bragunsky" of republican significance, located on the territory of three districts of the Chechen Republic (area of 17,000 hectares, forest land -- 10.2 thousand hectares) is studied. Its boundaries are indicated. Preliminary studies in the summer-autumn flora of the reserve have revealed 237 species from 175 genuses and 53 families, among which more than 15 endemics are of different statuses, 25 relict species are of different geological eras. Dominant by the number of family species are indicated (Asteraceae, Lamiaceae, Rosaceae, Poaceae, Fabaceae, Caryophyllaceae, Apiaceae, Brassicaceae, Cyperaceae, Scrophyliaceae, Orchidaceae), Geographic elements are considered. The general-holarctic and boreal nature of the flora is noted with a significant participation of ancient mediterranean and binding elements. The prevalence of hemicryptophytes in the reserve flora has been noted -$115(49.78 \%)$ species, 48 therophytes $(20.25 \%)$ and 40 phanerophytes (10 \%) and a slight presence of cryptophytes -- $4.21 \%$. The economically and scientifically valuable, as well as rare, red book and protected species are listed.

Keywords: Bragunsky reserve, flora, geo-elements, life forms, rare species, protection.

\section{Introduction}

Currently, only national parks and reserves are able to truly protect the whole diversity of living organisms, useful plants. In this regard, relevant is the real degree of knowledge of their nature, and, primarily, vegetation cover. Floristic reports containing comprehensive information on the species composition of plants, their geographical distribution, habitat conditions, occurrence, are the scientific basis for the development of measures to protect their gene pool [1--10]. floristic study of the forests of these territories is of productive and practical importance, especially for the correct assessment of their 
phytoresource potential, reforestation and organization of nature conservation activities in the reserve.

\section{Methods and Materials}

The object of the study is flora of the state biological reserve "Bragunsky". The concept of "flora" covers all floristic complexes that are formed on different substrates.

The material for this article is the expeditionary research conducted in 2010--2018 by the staff of the Academy of Sciences of the Chechen Republic and Kh. Ibragimov Complex Institute of the Russian Academy of Sciences at the reserve territory. In the summer-autumn periods, various sites and habitats of the reserve have been visited. The species composition of the flora, distribution and occurrence of specific species are taken into account. Herbarium material, replenished the collection fund of $\mathrm{Cl}$ RAS, and photographic materials have been collected.

The 3 volumes of "Flora of the North Caucasus" by A.I. Galushko is used to clarify the types [11].

Scientific (Latin) names of the species, genuses and families are given by S.K. Cherepanov [12].

\section{Results}

The state biological reserve "Bragunsky" is located in the Chechen Republic, at the confluence of the river Sunzha into Terek. Its territory is located at the junction of the Grozny, Gudermes and Shelkovsk districts. The reserve was created in 1971 with the aim of preserving, restoring and reproducing valuable, rare and endangered species of animals, plants and their environment, migration routes, nesting sites and maintaining ecological balance.

It has the status of a specially conserved natural territory of a regional (republican) significance. The reserve area is 17,000 hectares, including 10.2 thousand hectares of forest land.

Braguna and Darbanha villages are located on the territory of the reserve.

The northern boundary of the reserve begins three kilometers below the village of Vinogradnoe along the river of Terek and passes to Chervlennaia-Uzlovaia forest. Then -- along the western border of the forest to the intersection of the channel by rail and along the channel to the east up to the eastern border of the forest. After 
that, again to Terek, then down the river to the eastern border of the 23rd section of the Gudermes Forestry. Southeastern border runs from the 23rd quarter along the shaft of the Khangish-lurt highway -- Gudermes up to 25th section and further along forest border to the south side of the 15th section of the Gudermes Forestry. Then -- across the railway bridge on Sunzha to the south side of the 37th section of the Goriacheistochnenskii Forestry. South-western border runs from 3rd section along the forest border of $33,32,29,27,23,15$ sections and up to the western side of the 14th sections of the Goriacheistochnenskii Forestry, the western border -- along the western side of the 14th section.

A list of the local flora was compiled for the studied area of Bragunsky reserve, the phenological state of each species was noted, its occurrence in a given territory, the status of their populations, and a scientific herbarium was collected. In cameral terms, by determinants of A.A. Grossgeim [13, 14], A.I. Galushko [15] and "Trees and Shrubs of the North Caucasus" $[2,3]$ the species affiliation of plants was clarified.

Considering the phyto-diversity of flora, different periods of vegetation, flowering and fruiting of species, for a more complete account of them, the same territory was visited at different times. For this reason, some areas of the reserve, being unexplored, need additional research.

Having clarified the identified species for the visited territories, a systematic summary list of flora is drawn up, indicating the families, Latin and Russian names of plant species.

During the expeditions, field recordings were made; illustrative material was prepared (photographs of specific plant species, various plant groupings and landscape types). These materials will be used in the preparation of a detailed report and scientific publications.

A systematic list of vascular, floral (bilobular) plants of the investigated part of the "Bragunsky" reserve is below. For ease of use, families and types are arranged in the order of Latin alphabet.

\subsection{Systematic structure of the flora of the biological reserve "Bra- gunsky"}

One of the most important characteristics of the flora is the total number of its constituent species that is systematic composition, serving as an indicator of its quantitative state. Bragunsky reserve flora includes 237 species of vascular plants belonging to 175 genuses and 53 families. The structure of the flora is revealed when considering the composition and determining the role of the leading ones by the number of taxons 
-- families and genuses. In the study reserve, the most common types of families: Asteraceae -- 37, Lamiaceae -- 21, Rosaceae -- 20, Poaceae -- 23, Fabaceae -- 11, Caryophyllaceae -- 11, Apiaceae -- 11, Brassicaceae -- 11, Cyperaceae -- 12, Scrophyliaceae -- 10. Orchidaceae -- 3. Generic coefficient, representing the ratio of the number of species to the number of genuses, is equal to 1.62 .

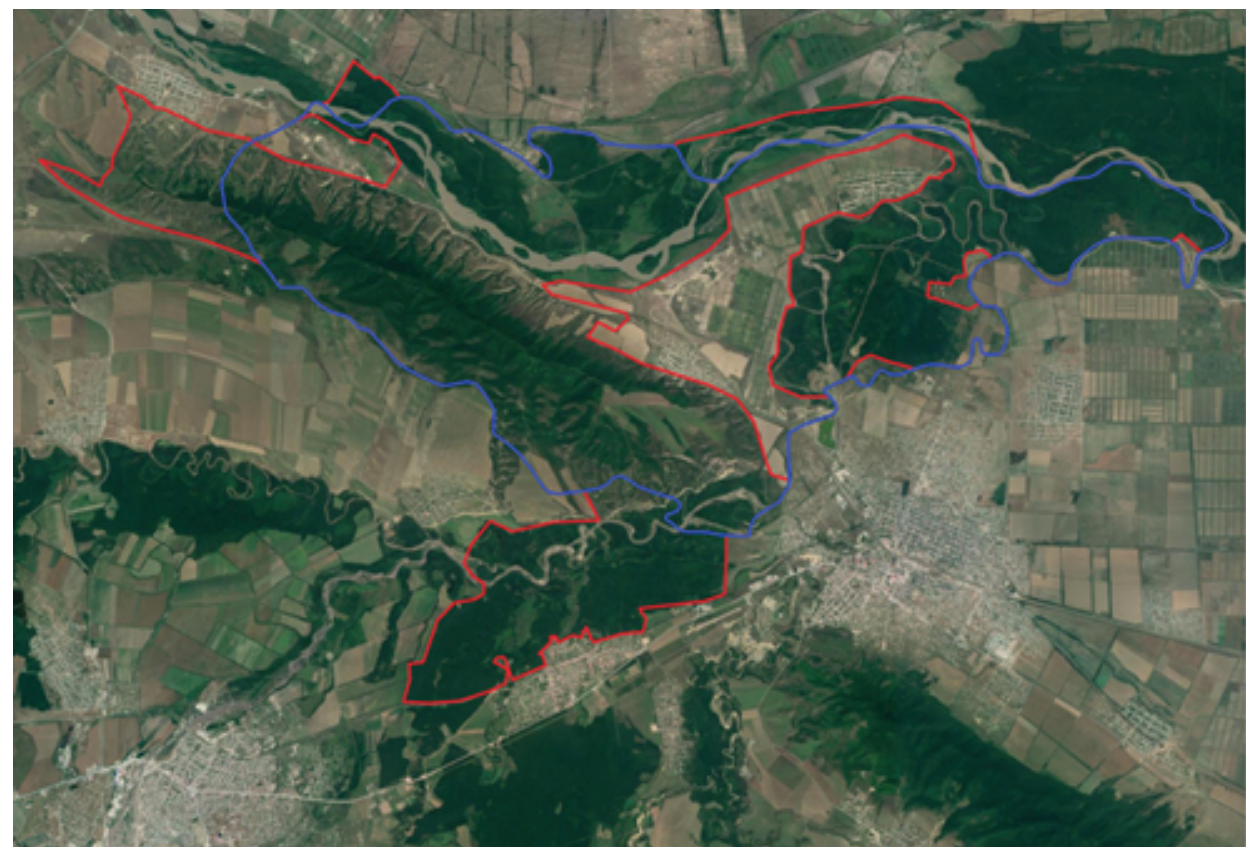

Figure 1: New map-scheme of the Bragunsky reserve.

Geographical analysis. An integral part of the flora analysis is the selection of geographic elements, that is, the division of the studied flora into groups of species that have a similar distribution. In the studied flora, 22 geo-elements are integrated into 6 groups (geo-types): plural-regional, general-holarctic, boreal, ancient mediterranean, binding and adventitious species.

The ratio of the quantitative composition of geo-element groups of the Chechen Republic flora is given in Table 1.

TABLE 1: Ratio of geo-element groups of the Chechen Republic flora.

\begin{tabular}{ll|} 
№ & Geo-element group \\
1 & Plural-regional \\
2 & General-holarctic \\
3 & Boreal \\
\hline 4 & Ancient mediterranean \\
\hline 5 & Binding \\
6 & Adventitious
\end{tabular}

\begin{tabular}{|c|}
\hline Quantity of types \\
\hline 8 \\
\hline 79 \\
\hline 68 \\
\hline 47 \\
\hline 29 \\
\hline 6 \\
\hline
\end{tabular}

Participation \%
$\begin{array}{r}3,37 \\ 33,33 \\ 28,69 \\ 19,83 \\ 12,23 \\ 2,53\end{array}$


TABLE 2: Biomorphological spectrum of the Bragunsky reserve flora.

\begin{tabular}{|l|c|c|c|c|c|c|c|c|}
\hline BIOMORPH & \multicolumn{3}{|c|}{$\mathrm{Ph}=40$ (10,0 \%) } & Ch & HK & K & T \\
\cline { 2 - 12 } & Phmg & Phms & Phm & Phn & & & & \\
\hline Number of species & 2 & 10 & 11 & 17 & 15 & 115 & 10 & 48 \\
\hline \% of the total & 0,84 & 4,21 & 4,64 & 7,17 & 6,33 & 48,52 & 4,21 & 20,25
\end{tabular}

Under biomorphological analysis of flora (Table 2), the greatest participation of hemicryptophytes is noted in it, numbering 115 (49.78 \%) species, that is, about 2/3 of the total local flora. Therophytes of 48 (20.25\%) species take the second place. Phanerophytes of 40 (10\%) species take the third place, among which nanophanerophytes of 17 (7.17 \%) flora species dominate; in this biomorph they account for 42.5 $\% .15(6,32 \%)$ species of chamephytes in the studied flora. The least represented are cryptophytes -- 10 (4.21\%) species.

Rare and protected species. The analysis of the areas and state of populations revealed that 22 species of rare plants listed in the federal and regional Red Books need protection [1, 5]: Caspian onion (Allium caspium), Armenian althea (Althaea armeniaca), Althea officinalis (Althaea officinalis), Brachylobus astragalus (Astragalus brachylobus), Karakuginskii astragalus (Astragalus karakugensis), Lehmann astragalus (Astragalus lehmannianus), long-flowered astragalus (Astragalus longipetalus), Volga calophaca (Calophaca wolgarica), Bulgarian cleistogenes (Cleistogenes bulgarica), Oriental clematis (Clematis orientalis), (Crypsis aculeate), quince tree (Cydonia oblonga), moccasin flower (Cypripedium calceolus), lanceolate carnation (Dianthus pallens), variable carnation (Dianthus polymorphus), two spikelet ephedra (Ephedra distachya), ramose horsetail (Equisetum ramosissimum), eremosparton apophyllous (Eremosparton aphyllum), Ravenna grass (Erianthus ravennae), undulate euphorbia (Euphorbia undulate), Caspian ferula (Ferula caspica), yellow everlasting (Helichrysum arenarium), alang grass (Imperata cylindrical), yellow iris (Iris pseudacorus), wide-leaf sea lavender (Limonium platyphyllum), sand poppy (Papaver arenarium), Grecian silk vine (Periploca graeca), willow-leaf pear (Pyrus salicifolia), Palasian thyme (Thymus pallasianus), Bieberstein tulip (Tulipa biebersteiniana), Schrenkii astragalus (Tulipa schrenkii), woodland grape (Vitis sylvestris).

Relic, valuable in economic and scientific relations species are subject to strict protection, as well as areas of natural semi-desert vegetation and relict forests along former river beds and reservoirs.

Plant resources of the reserve. The reserve flora is rich in plants used in various fields of national economy. The following useful groups are identified: medical, 
food, fodder, poisonous, decorative, prone-fixative. These include: ramose horsetail (Equisetum ramosissimum), marsh shield fern (Thelypteris palustris), yellow centaury (Centaurea solstitialis), toryweed (Cynoglossum officinale), goat-leaf honeysuckle (Lonicera caprifolium), lanceolate carnation (Dentaria lanceolatus), dendroid salt grass (Salsola dendroides), paniculate gypsophila (Gypsophila paniculata), corzonerifolial gypsophila (Gypsophila scorzonerifolia), Lehmann astragalus (Astragalus lehmannianus), common licorice (Glycyrrhisa glabra), yellow melilot (Melilotus officinalis), Chian bugleweed (Ajuga chia), Palasian thyme (Thymus pallasianus), Armenian althea (Althaea armeniaca) and althea officinalis (Althaea officinalis), white mulberry (Morus alba), black mulberry (Morus nigra), glossy buckthorn (Frangula alnus), purging buckthorn (Rhamnus cathartica), spatulate-leaf buckthorn (Rhamnus spathulifolia), common agrimony (Agrimonia eupatoria), common apricot (Arminiaca vulgaris), close-meiostemonous thorn (Crataegus curvisepala), single-seed hawthorn (Crataegus monogyna), alycha (Prunus divaricata), steppe plum, blachthorn (Prunus stepposa), Caucasian pear (Pyrus caucasica), corymb rose (Rosa corymbifera), wild rose (Rosa canina), dewberry (Rubus caesius), speedwell (Veronica spicata) [1, 5].

\section{Conclusion}

According to our preliminary calculations, over 25 species of plants with medical use are growing in the Bragunsky reserve. Some of them can be used for food, including fruit and berry and nut plants. The group of food plants includes 20 species. Many fodder $(60$ species), as well as suitable for use in ornamental gardening when planting of greenery streets and other settlements (about 50 species). There are about 20 species in the prone-fixative group. 15 species are poisonous plants that cause poisoning in livestock, less in humans.

With the rational use of plant resources, the Bragunsky reserve can serve as an inexhaustible source of valuable food, medical, technical and other useful plants.

There are species included in the "Red Book of the Chechen Republic" in the reserve flora [16, 17]: two spikelet ephedra, common smoke tree, Grecian silk vine, oriental apple tree, Russian almond, willow-leaf pear, Iberic madder, woodland grape, Ravenna grass, quince tree.

Geographical analysis indicates a general-holarctic and boreal nature of the studied flora, since this group contains more than half of all floras. The identified floristic composition of the Bragunsky reserve includes 237 species from 175 genuses and 53 families. More than 15 endemics of various statuses and 25 relict species of various 
geological eras grow in the reserve. The plants used in the national economy are described.

Plants with useful properties in the composition of the studied flora are represented by melliferous, fodder, food, decorative, medicinal plants and comprise 52 species.

\section{References}

[1] Taysumov, M.A., Omarkhadzhieva, F.S. (2012). Analysis of the flora of the Chechen Republic. Grozny, 320 p.

[2] Galushko, A.I. (1975). Vegetative cover of Chechen-Ingushetia. Grozny: ChechenIngush Book Publishing House, 118 p.

[3] Trees and shrubs of the North Caucasus. (1967). Nalchik, 534 p.

[4] Umarov, M.U., Taysumov, M.A. (2009). Dendroflora of the Chechen Republic: Latin, Russian and Chechen names. Bulletin of the Chechen State University, iss. 1, pp. 96--104.

[5] Umarov, M.U. (2003). Plant resources of the Chechen Republic, prospects for use and protection. Mater. All-Russia scientific conference. Grozny, p. 188--224.

[6] Umarov, M.U., Taysumov, M.A. (2014). Tertiary relics of the flora of the Chechen Republic. Bulletin of the Academy of Sciences of the Chechen Republic, iss. 2(23), pp. 34--41.

[7] Grossheim, A.A. (1952). Plant wealth of the Caucasus. Moscow, 630 p.

[8] Taysumov, M.A., Umarov, M.U., Astamirova, M.A., Abdurzakova, A.S., Khalidova, Kh.L. (2015). The species potential of useful plants of mountainous regions of the Chechen Republic. Bulletin of Crass GAU, iss. 1, pp. 149--155.

[9] Taysumov, M.A.. Umarov, M.U.. Abumuslimov, A.A. (2009). To the steppe flora of the Chechen Republic. Mater. V Intern. symposium. Orenburg: IPP Gazprompechat LLC Orenburggazpromservis, pp. 641--643.

[10] Taysumov, M.A., Umarov, M.U., Magomadova, R.S. (2016). Analysis of the vegetation cover of the tract Kiisyk Shelkovsky district of the Chechen Republic. News of the $D S P U$, no. 1, pp. 34--41.

[11] Galushko, A.I. (1978--1980). Flora of the North Caucasus, vol. 1, 1978, 317 p.; vol. 2, 1980, 350 pp.; vol. 3, 1980, 327 p. Rostov-on-Don: RSU.

[12] Cherepanov, S.K. (1995). Vascular plants of Russia and adjacent states. St. Peterburg: Peace and Family, 990 p. 
[13] Grossheim, A.A. (1936). Analysis of the flora of the Caucasus: Proceedings of the Botanical Institute of Azerbaijan. FAN USSR, vol. 1. Baku, 260 p.

[14] Grossheim, A.A. (1948). Vegetation cover of the Caucasus. Moscow: Publishing house MOIP, $267 \mathrm{p}$.

[15] Galushko, A.I. (1964) The determinant of plants of hayfields and pastures of the North Caucasus. Uchenye zapiski Kabardino-Balkarskogo gos. unta Biology series, vol. 23, pp. 1--372.

[16] The Red Book of the Chechen Republic. (2007). Grozny, 432 p.

[17] The Red Book of the RSFSR, vol. 2. (1988). Moscow: Rosagropromizdat, 598 p. 